\title{
OBITUARY .
}

Professor SYDNEY CHAPMAN, FRS, died on 16 June 1970 at the age of 82 . It may be some time before we see his like again, but Chapman's continual and increasing flow of ideas was so forward-looking that it will be some years yet before we catch up with all of them.

In 1910, after taking an engineering degree at Manchester and the mathematical tripos at Cambridge, he worked at the Royal Observatory, Greenwich, as chief assistant, until he returned to Cambridge with a fellowship at Trinity College in 1914. During this period his mathematical work was in the kinetic theory of gases, in particular the extension to non-uniform gases and mixtures. This research was later collected into a book, The mathematical theory of nonuniform gases (1939, London), written with T. G. Cowling. This work found many applications, of which the most notable is perhaps the separation of isotopes. The book also included the first results in the dynamical theory of plasmas.

Chapman was elected a Fellow of the Royal Society in 1919 and held professorships at Manchester (1919-24), Imperial College (1924-36), and Oxford (1946-53). Throughout this period, his sustained interest in geomagnetism led him to the study of oscillations of the Earth's atmosphere, and polar aurora. In these papers herculean statistical analyses of magnetic storm data were characteristically followed up by theoretical discussion of the results. Early contributions to the theory of magnetic storms and aurora appeared as the Adams Prize Essay in 1929, and proved to be the starting point for the standard monograph Geomagnetism, written in collaboration with J. Bartels (1940. Oxford).

His study of the atmosphere, which involved the interpretation of geomagnetic variations, led to a classical paper on the theory of the formation of an ionospheric layer, (Proceedings of the Physical Society, Vol 43, No 236 and 240, 1931, p 26-45, 483-501) still referred to in the literature as a Chapman distribution, and to the correct interpretation of the origin of the ozone layer in the atmosphere.

Between 1950 and 1953, momentum was gathering for another International Polar Year, and Chapman's retirement from Oxford came just in time for him to play a leading part in it. Events as great as the International Geophysical Year (IGY) are rarely traceable to a single conception, but there seems no doubt that this idea was born at a small discussion group in 1950, at the home of James Van Allen in Washington, when the guests included Chapman and Lloyd Berkener. Chapman himself later proposed the name International Geophysical Year which was approved at the ICSU Assembly in Amsterdam in 1952. In Bruxelles in 1953 the IGY Special Committee (CSAGI) elected Chapman president. Planning was well advanced by 1954 when CSAGI met in Rome, and, for the first time, the SSSR Akademia Nauk [Academy of Sciences] participated. Chapman's diplomacy at this meeting eased their full entry into the programme and he began to woo the Chinese Peoples Republic 
through their membership in scientific unions. These negotiations, so nearly successful, did not finally break down until 1957 but it seems that China nevertheless carried out most of the programme planned by CSAGI.

Retirement from Oxford at the age of 65 and president of the committee planning an international scientific programme: an end of original work? Chapman now took up posts at the High Altitude Observatory, in Boulder, Colorado, and at the Geophysical Institute, in College, Alaska, and accelerated his flow of scientific papers, which averaged one every two months for more than 50 years. A high proportion of his later papers were concerned with theories of magnetic storms and aurorae. There is no doubt that he found direct contact with practical observers in Alaska to be stimulating and, equally, that he spurred them to greater efforts in following up his suggestions.

It would be difficult to overestimate Sydney Chapman's influence on the scientific world at large. He was president of the International Association for Meteorology (1936-48), the International Association for Terrestrial Magnetism and Electricity (1948-51), and UGGI (1941-54), London Mathematical Society, Royal Meteorological Society, Royal Astronomical Society, and Physical Society. He was elected to numerous foreign academies and received many honorary degrees.

Stories of his cycling, swimming, and walking feats are legendary: for a collection we commend a Fetschrift from his friends on the occasion of his eightieth birthday: Sydney Chapman, eighty (Akasofu, Fogle, and Haurwitz, eds, University of Colorado Press, Boulder, 1968). In spite of all his achievements in making geophysics a subject of truly world-wide study, it will be his simplicity and kindness that will always be remembered by many friends.

STANLEY EVANS

Vice-Admiral RICHARD L. CRUZON, USN, who commanded United States Naval ventures in both the Arctic and the Antarctic, died on 15 April 1970 at the age of 72 .

He graduated from the United States Naval Academy in 1919 and, as lieutenant-commander, was second-in-command to Rear-Admiral R. E. Byrd, USN, in USS Bear during the United States Antarctic Service Expedition, 1939-41. He served with the Seventh Fleet in the south-west Pacific Ocean during the Second World War then, in 1945, he commanded a four-month naval Arctic cruise making navigational and weather observations. In 1946 he commanded USS Mount Olympus during "Operation Highjump" in Antarctic waters. His final command before his retirement in 1954 was of United States naval forces in the Philippine Islands.

Vice-Admiral Sir ARCHIBALD DAY, CB, DSO, former Hydrographer of the British Navy, died on 17 July 1970 , aged 70.

He was born on 18 July 1899 and passed from HMS Conway to the Royal Naval College, Dartmouth, where his normal training was interrupted by the outbreak of the First World War. He went to sea in the Mobilization Fleet in August 1914, after only one term at the college. By the time he was 18, 
he had seen service as cadet and midshipman in the North and Mediterranean seas. From 1937 to 1940, he was Superintendent of Charts in the Hydrographic Department and was then appointed Chief Staff Officer to the Flag Officer, Dover, and played a major part in the evacuation from Dunkirk and other French ports and beaches. He returned to the Hydrographic Department for 1943 and 1944, but ended the Second World War in command of HMS White Bear in far eastern waters.

After the war, he again held the post of Assistant Hydrographer, commanded HMS Dalrymple surveying in the Mediterranean Sea, was promoted RearAdmiral in 1949, and appointed Hydrographer of the Navy a year later. He held this post for five years during which he was appointed Vice-Admiral. Immediately after retiring in 1955 , he led a unit making the first modern hydrographic survey of Lake Nyasa. In 1956, he returned to Europe to spend three very active years in Bruxelles as Co-ordinator of Operations for the International Geophysical Year, a post he filled with competence and enthusiasm. From 1961, he had served as Acting-Conservator of the River Mersey and on the board of the Port of London Authority.

In 1967, he published The Admiralty Hydrographic Service 1795-1919 (HMSO), a review of British hydrographic history.

G. WILLIAM HOLMES, a glacial geologist serving with the United States Geological Survey, died on 7 January 1970 at the age of 47 . He graduated from Carleton College, Minnesota. in 1943 and saw service in the United States Air Force during the Second World War before returning to Harvard University to gain his $\mathrm{PhD}$ in 1949 and then becoming head of the Department of Geology at Beloit College in Wisconsin. In 1955 he transferred to the Geological Survey and worked in Alaska Range, then helped to establish the Arctic Research Laboratory's field research station at Lake Peters, Alaska, in 1958.

THOMAS JOHN HART, the distinguished British authority on marine diatoms, died on 4 May 1970.

He was born in Cambridgeshire in 1907 and was educated at Lady Manners School, Bakewell, and Leeds University, where he graduated in zoology with first-class honours in 1929. In the same year he joined the Discovery Investigations, serving on RRS Discovery II in the Southern Ocean on her 1st, 3rd and 5th commissions (1929-31, 1933-35, and 1937-39); he served also in RRS William Scoresby in 1936-37 and 1950. He obtained the degree of MSc in 1934 and a DSc for published work in 1935.

Despite his training in zoology, he was principally known for his work on phytoplankton and, in particular, for two Discovery Reports "On the phytoplankton of the south-west Atlantic and the Bellingshausen Sea, 1929-31" (1934), and "Phytoplankton periodicity in Antarctic surface waters" (1942), both of which are still widely read and cited. In 1946, he published another Discovery Report "Report on trawling surveys on the Patagonian Continental Shelf, compiled mainly from manuscripts left by the late E. R. Gunther, MA". The title reflects his characteristic insistence that proper acknowledgement be given to all who had contributed to a task even though, in this particular 
instance, he had re-calculated all the numerical data in the original log books and he had entirely rewritten the text.

In 1950, he sailed on William Scoresby as Principal Scientist to conduct a survey of the Benguela Current; however, ill health forced him to leave the ship at Cape Town at the end of the first survey. He published preliminary accounts of the Benguela Current plankton investigations in 1953 and was joint-author with R. I. Currie of a Discovery Report "The Benguela Current" (1960). In later years he worked on the skin film diatoms of whales and on 'discoloured water' phenomena, the latter work being based on samples collected by merchant ships by arrangement with the Meteorological Office. In 1966 he published a paper "Observations on the relative abundance of marine phytoplankton populations in nature" (in: H. Barnes ed. Some contemporary studies in marine science, London), which brought together much information on the enormous variation in numbers that can occur in the natural populations of the sea.

Hart joined the National Institute of Oceanography in 1949 and was employed there until his death. A quiet man with a dry and penetrating sense of humour, he was always ready to help colleagues from his immense knowledge of marine biological literature and from his practical experience of the plants and animals in the sea. He was awarded the Polar Medal in 1940 for his service in the Antarctic during the Discovery Investigations and always took a keen interest in Antarctic affairs.

P. M. DAVID

HARRY W. ROSS, who was Executive Officer of Nautilus in which Sir Hubert Wilkins attempted the first under-ice crossing of the Arctic basin in 1931, died in Washington, DC, on 13 December 1969 at the age of 78. Born in Segiun, Texas, Ross served in the United States Navy on submarine and mine sweeper duty during the First World War and in the Maritime Service during the Second World War, when he took part in the Allied invasion of North Africa and Sicily. In civilian life he was a compositor, working for various New York papers and for the Washington Post from 1953 until his retirement in 1965.

JACQUES ROUSSEAU died at his summer home near St-Donat, Quebec, on 4 August 1970. His early death was not unexpected, for he had already suffered several heart attacks. Born in 1905, at St-Lambert, Quebec, his education was in the schools of the province and his degrees from the Universite de Montréal (BA, 1926; LèsSc, 1928; DSc, 1934). His training was in botany and, from 1944 onward, he led a series of major expeditions into the northern parts of the Quebec-Labrador peninsula, which greatly advanced knowledge of that vast region. Rousseau's omnivorous curiosity drove him to become expert, not only in his chosen subject, but also in ethnology, geography, language, history, and much else. He combined a brilliant mind and polemical disposition with a powerful literary style, eloquent speech, and untiring energy. (After his first serious heart attack, he complained bitterly that his doctors would not let him work more than eight hours a day.) He published some 550 
works on a wide variety of subjects, but mainly on botany, created some 130 botanical entities, participated in a host of learned societies and other organizations, travelled and lectured widely, and held important administrative positions.

He was, with Frère Marie Victorin, co-founder of the Jardin botanique de Montréal in 1938 and director of it from 1944-56. In 1956, he became the first director of the National Museum of Man in Ottawa. He left this office in 1959, after a dispute, to become an associate professor in the Sorbonne. He returned from this self-imposed "exile" (as he termed it) to join L.-E. Hamelin, who had just established, in the Institut de Géographie of Université Laval, the Centre d'Etudes Nordiques.

My own first meeting with this great good man was in 1954 during a casual visit to his Jardin botanique. With the utmost enthusiasm, he encouraged my dawning interest in northern Quebec and, over the years, through patient correspondence and delightful conversation, he continued that cordial kindness to which a student cannot fail to respond. I never ceased to be amazed by the width and depth of his knowledge, not of his many academic specialities only, but of any subject that came into sight or hearing. My last meeting with him was in November 1969. He had just left hospital, after another heart attack, to attend a conference in France on the future of Eskimo societies. He stopped in Cambridge to see his youngest son, Jérôme, a research student in anthropology, and to read at Professor Rich's invitation a paper on early French relations with the Eskimos of Labrador-a memorable evening. As I intended to attend the same conference, he asked me to travel with him. "I do not wish to die in the presence of strangers. And the taxi drivers of France may yet kill me." He survived the journey without noticeable fatigue, attended every session, and was, without question, the star of the occasion. His final speech was a masterpiece of rhetoric, wit, wisdom, and warmth. He intended, he concluded, to return that night to Canada, for he had immediately to attend another conference, this one devoted to problems of students in Quebec. $\mathrm{He}$ had been elected to participate in it, he explained, not because of his age and experience, but in spite of it. A group of students had chosen him to represent their views!

Although Rousseau had the compassion and dignity of a saint, he also had enemies. In that final speech in France, he admitted in a graceful aside that he had made mistakes "dans une vie peut-être trop excitée." Perhaps he had. But he had been born a fighter for truth and justice, and, on points of principle, he was like granite. To grow up a fighter for such principles in the French Canada of his youth was neither easy nor pleasant. To fellow scholars and to friends the world over, he represented what was best in a noble tradition that, through the centuries, had flourished obscurely in a cold corner of the New World. Although intensely one of his own people, he was in many senses deraciné and a citizen of the world. In his last years, knowing better than most men that his days were numbered, he worked, travelled, and lived day-to-day with tranquil intensity. 
Professor JOHAN T. RUUD, the eminent Norwegian marine biologist and university administrator, died on 11 January 1970 , at the age of 66 . He was a man of remarkable all-round abilities and achievements and was held in great respect and affection by numerous colleagues in many countries. For some 30 years he was Professor of Marine Biology at the University of Oslo, and had many other responsibilities, for he was also Director of the University's Institute of Marine Biology and the State Institute of Whale Research, and served as Rector of the University for two terms of three years. From his early youth onwards he gained much practical experience of the sea, especially in oceanographical research in Norwegian waters. In 1929 he took part in the Ost expedition to East Greenland, and later in that year sailed in the whaling factory ship Vikingen for a season's work on whales and plankton in the Antarctic. In the later months of 1953 he took charge of a whale-marking expedition in the Antarctic in the whale catcher Enern.

In the earlier part of his career he worked under Professor Johan Hjort with whom he collaborated in some of the first investigations of the biology of the stocks of whales, the effects of modern whaling and problems of conservation. His memoirs on the Euphausiacea including the Antarctic krill, published in the 1930's, are well known to workers on this group, and his subsequent work included the demonstration of a new method of finding the ages of whales through the growth of the baleen plates, and a study of the physiology of the 'bloodless' Chaenichthyid fishes in the Antarctic.

The quality of these researches must make them of permanent value, but Ruud will perhaps be remembered even more for his capacities as an administrator and as an influential figure in national and international bodies. Apart from his academic responsibilities he was deeply committed to the work of the International Council for the Exploration of the Sea, of which he was a Vice-President for some years, and of the International Whaling Commission in which he was at one time Chairman of the Scientific Committee. His was a strong voice in support of the conservation of exploited marine populations, not only at formal meetings but also in informal discussions, for he knew exactly how to talk to scientists, administrators, and industrial leaders, and to argue his case in a way that even a determined opponent would find hard to resist.

An obituary notice would be incomplete without a word on his personal qualities, for it is not too much to say that in a lifetime one could meet few people of such exemplary character. $\mathrm{He}$ was an unassuming man whose generosity and complete integrity could always be relied on, and his many friends naturally turned to him for advice and help in professional and personal difficulties. On social occasions his tall slim figure, straight as a lamp-post, could usually be picked out at the centre of the largest group where the most interesting and cheerful discussion was going on, and whatever the subject he would have stimulating ideas or appropriate anecdotes to contribute to it. Learning, responsibility, expeditions and adventures all suited his tastes and abilities, and skiing especially was a congenial recreation even to the end of his life. 
JOHN CAMPBELL SPROULE died in Jasper, Alberta, on 21 May 1970, while attending a meeting of the Western Congress of Engineering at which he had presented a paper on oil exploration in the Canadian Arctic islands.

Sproule was born in Edmonton, Alberta, on 13 May 1905. In 1930, he received a BSc in geology from the University of Alberta and, in 1935, a doctorate from the University. of Toronto. Between 1931 and 1939, he was successively a lecturer at the University of Toronto, a geological specialist with the Mines Branch, and a member of the Geological Survey of Canada. In 1939, he joined the Imperial Oil Company and, until 1946, he was manager and geologist for that firm's exploration programme in Saskatchewan. After 1946, he worked for the International Petroleum Company.

He left International Petroleum in 1951, a decision prompted, in part, by his determination to stay and work in Canada. In that year, he founded his own consulting firm, J. C. Sproule and Associates Limited, Calgary. It was a relatively rare venture for a Canadian and a local Albertan to attempt to go into business for himself in an industry dominated by foreign capital and by major, international oil producers. He was successful and his firm grew to be one of the largest of its kind in Canada.

He had a long-standing interest in the Canadian north. His work and experience ranged from the Athabasca Tar Sands of Alberta to the sediments of the high Arctic. The climax of this interest was the leading part he played in the formation, in 1967, of Panarctic Oils Limited, a consortium of private and federal government investment for the exploration of the Canadian Arctic.

ANDREW A THOMPSON, who led the geophysical research team during the Ronne Antarctic Research Expedition, 1947-48, died in Baltimore on 17 September as a result of injuries suffered in a motor accident. He was 46 years old. Thompson received his bachelor's degree in physics from Yale University in 1945 followed by a master's degree in geology from Columbia University. In recent years he had been a research geophysicist in the exploration and kinetics branch of the United States Army Ballistic Research Laboratories, Aberdeen Proving Grounds, Maryland. 